\title{
The Justiciability of the Right to Development in Ghana: Mirage or Possibility?
}

\author{
Asare Larbi Paa Kwame*
}

\begin{abstract}
An analysis of the debate on the right to development (RTD) suggests that the right is pursued as a solution to solve the problems of poverty and underdevelopment. Thus, this study seeks to determine if at the national level in Ghana, the right to development is a right which is opposable by right-holders against the duty bearers. The Study adopted the Black Letter Law approach in analysing the legal effect of relevant law.

This study shows that the African Charter is the only multinational treaty that makes RTD legally enforceable. It also shows that Ghana, which is dualist, has not ratified the African Charter. It is however argued that the Ghanaian courts may enforce RTD either as international law or as a human right implicitly guaranteed under the 1992 Constitution of Ghana. This conclusion supports the notion that development is a human rights concern. It further illustrates that the national courts of African countries are uniquely equipped to guarantee the protection of human rights and the development of the African people.
\end{abstract}

\section{Introduction}

The world, as we know it today, is characterised by vast and deep-rooted inequalities among States. Following the establishment of the United Nations (hereinafter referred to as the UN) and the realisation of world peace and security, the question as to whether the international community bears some responsibility for assisting states whose resources are inadequate to ensure the human rights of their own citizens, or for providing direct assistance to those individuals

* The author is an LL.B graduate from the Kwame Nkurumah University of Science and Technology in Kumasi, Ghana. 
in dire need has been the subject of intense debate. ${ }^{1}$ Since 1977, much of this debate has been pursued within the field of human rights under the rubric of the 'right to development.'

In international discourse, there has been relentless debate on the validity of this right to development. In 1977, however, the UN Commission on Human Rights recognized the right. It was then enshrined by the General Assembly in the 1986 Declaration on the Right to Development (hereinafter referred to as the UNDRD). ${ }^{3}$ Yet even after this occurrence, the question of whether the right to development is even a right remains a contentious one.

On one side of this debate are developing countries who are proponents of the right to development. One of the arguments advanced by such developing economies is that the right to development is built on the principle of international solidarity that obliges developed nations to support developing ones to attain development. ${ }^{4}$ On the other side are some donor countries like the United States; that reject the existence of such a right and alternatively argue that the duty is incumbent upon any nation to ensure that its human rights regime is conducive enough to encourage development. ${ }^{5}$

It is submitted that the backdrop against which it is argued that the developed countries of the world should support developing ones to attain development is the glaring hardship and poverty that characterises third-world economies mostly found on the African continent. It will therefore appear that the right to development is pursued as a solution to the problems of poverty and under-development. Thus, this study shall seek to determine whether, at the national level in Ghana, the right to development is a right which is opposable by right holders against the duty bearers. Is it a justiciable right? Is it legally enforceable through the means of legislation and legal policy?

Steiner $\mathrm{J} \mathrm{H}$ and Alston P, International human rights in context; law, politics, morals, text and materials, 2ed, Oxford University Press 2000, 1319.

2 Steiner and Alston, International buman rights in context; law, politics, morals, text and materials, 2ed, 1319.

3 Steiner and Alston, International buman rights in context; law, politics, morals, text and materials, 1319.

4 Steiner and Alston, International buman rights in context; law, politics, morals text and materials, 1319.

5 Marks S, 'The human right to development: between rhetoric and reality' Vol 17 Harvard Human Rights Journal (2004), 137. 


\section{The Concept of Development}

The concept of development connotes progress particularly the economic wealth and fortitude of a state. This, more often than not, translates into improvement in the national GDP, balance of payments and similar economic indicators. In recent discourse, the concept of development is understood to go beyond economic statistics and enter into the realm of actual satisfaction of human needs and freedoms. ${ }^{6}$ For instance in Ghana, the concept is said to mean the 'satisfaction of basic needs." In this light, it becomes clear how development becomes a subject of human rights.

It has been suggested that there are generally two attitudes towards the process of development. ${ }^{8}$ The first approach is 'fierce' whereas the other approach is essentially a 'friendly' process. ' For the purposes of this study, the fierce approach shall be referred to as the 'Hard Knocks Theory' whereas the friendly process shall be referred to as the 'Liberal Theory of Development.'

\section{i. The Hard Knocks Theory}

This theory sees development as a 'fierce' process. This fierce process does not make room for certain polices that may be considered as 'soft-headed. ${ }^{10}$ Examples of such soft-headed policies include social safety nets for the poor such as welfare schemes and the provision of social services for the population at large. Such soft-headed policies are considered the 'luxury of democracy' which may be adopted only at the end of the developmental process. ${ }^{11}$ The theory prioritises economic development and concentrates on improving the GDP of the nation, the balance of payments etc. Consequently, the 'luxuries of development' play second fiddle to the macro- and micro-economic progress of the nation.

The implications of such an approach are evident: the abuse of human rights, large scale deprivation of essential amenities to the poor and in some cases civil unrest and coup d'états. For instance, the Nkrumah administration

Aryeetey et al. 'The Right to Development Report, Ghana Country Study', unpublished report, Ghana Legal Resources Centre, December 2004.

Administrator of district assembly common fund, "Proposed formula for sharing the year 2001 district assembly common fund", Memo to parliament, June 7, 2001 [pg.2]

Sen A, 'Development as freedom' Oxford University Press (1999), 35.

Sen A, 'Development as freedom', 35.

Sen A, 'Development as freedom', 35.

Sen A, 'Development as freedom', 35. 
adopted this 'hard knocks' approach and while his regime produced some economic progress it was notorious for its mass human rights abuses which eventually culminated in his overthrow from power. ${ }^{12}$ This only goes to demonstrate the unsuitability of this approach in modern democracies.

\section{ii. The Liberal Approach}

The second approach is described as 'friendly' because it does not adopt the rugged and tough attitude of the 'hard knocks' theory. Unlike the fierce approach, this approach makes room for the inclusion of human freedoms and the so-called 'soft headed' policies. It views development as a process aimed towards the expansion of the 'real freedoms' that people enjoy. Therefore, development is targeted at reducing escapable morbidity, increasing literacy levels, political participation and also increasing the availability of basic necessities such as food, shelter and clothing. In this vein, expansion of human freedoms is viewed as both the primary end and the principal means of development. Human freedoms therefore play both a constitutive and an instrumental role in the process of development.

It may be observed that the focus of both theories is their distinguishing factor. Under the liberal theory, the focus is not mere economic gain but rather the expansion of human freedoms. This may be contrasted with the "hard knocks' theory which is aimed primarily at the attainment of national economic goals. It is submitted that it is this distinction that gives rise to the place of the concept of development in the human rights discourse.

\section{ii. The Right to Development}

RTD has been described as the alpha and omega of buman rights, the first and the last human right, the beginning and the end, the means and the goal of human rights; in short, it is the core right from which all the others stem..." ${ }^{13}$ This graphic description of RTD is one of the various ways in which writers have argued that the RTD is a fundamental human right that even pre-exists law. ${ }^{14}$ It has indeed been described as being as fundamental as the right to life. ${ }^{15}$

\footnotetext{
12 Aryeetey et al. 'The Right to Development Report, Ghana Country Study', unpublished report, Ghana Legal Resources Centre, December 2004.

13 Bedjaoui M, 'The right to development' in Bedjaoui M, International law; achievements and prospects, Dordrecht: Martinus Nijhoff and UNESCO 1991, 1177.

14 Bedjaoui, 'The right to development', 1177.

15 Bedjaoui, 'The right to development', 1177.
} 
Some commentators have also described the right as being a collective human right because it is an aggregate of the economic and cultural rights not of each individual, but of all individuals constituting a 'collectivity;' their right to an equitable share in the economic and social well-being of the world. ${ }^{16}$ In response to such propositions, others have argued that indeed the formulation of RTD is nothing more than a slogan. ${ }^{17}$ It has also been argued that the right to development is unnecessary because its contents are already firmly established by the right to self-determination which allows a people to choose their own economic and social systems without interference. ${ }^{18}$

In spite of the lack of apparent consensus on the right to development, recent international discourse will reveal that the question as to whether RTD is even a right has been settled. The General Assembly DRD established the right to development and defined it as 'an inalienable human right by virtue of which every human person and all peoples are entitled to participate in, contribute to, and enjoy economic, social, cultural and political development in which all human rights and fundamental freedoms can be fully realised. ${ }^{19}$ Although this declaration did not receive unanimous support, the 1993 Vienna Declaration and Programme of Action unanimously endorsed RTD and called it 'a universal and inalienable right and an integral part of fundamental buman rights. ${ }^{20}$ The following paragraphs shall briefly deal with the characteristics of the right to development.

First, the definition of RTD in Article 1 of the UNDRD has three principles: (a) that the right to development is an inalienable human right; (b) that there is a particular process of economic, social, cultural and political development which is conducive to the realisation of all human rights and fundamental freedoms; (c) that the right to development is a human right that entitles every human person and all peoples to participate in, contribute to and enjoy that particular process of development. ${ }^{21}$

16 See Abi-Saab G, "The legal formulation of a right to development", The right to development at the international level, The Hague, (1980)

17 Donnelly J, 'In search of the unicorn: The jurisprudence and politics of the right to development' 15 California Western International Law Journal (1985), 473.

18 Donnelly J, 'In search of the unicorn: The jurisprudence and politics of the right to development', 473.

19 Article 1, UNGA, Declaration on the Right to Development, U.N.Doc. A/RES>41/128(1986).

20 Vienna declaration and programme of action: note by the secretariat, world conference on human rights, Part I, [10, U.N. Doc. A/CONF. 157/23 (1993)

21 Kirchmeier F, 'The right to development- where do we stand?' Occasional Paper No. 23, Friedrich Ebert Stiftung, (2006), 9. 
Secondly, RTD embraces the arguments presented by both opposing sides on the meaning of the right. The right to development aims at ensuring development for both the individual and peoples on both national and international platforms. As provided for by Article 1 of the UNDRD, it is a right that 'every buman person and all peoples' are entitled to. ${ }^{22}$ RTD is therefore both an individual right exercisable against the state as well as a collective right exercisable against the international community.

Thirdly, RTD hinges on the principle that all fundamental rights and freedoms are indivisible and interdependent. It also requires that equal attention should be given to the promotion and protection of all rights because the promotion of certain rights and freedoms cannot justify the denial of others. ${ }^{23}$ To this extent, RTD embraces both 1977 Conventions and is viewed as a synthesis human right which goes beyond the mere aggregation of existing human rights. ${ }^{24}$ RTD thus finds expression in both civil and political rights on one side and social, economic and cultural rights on the other. At the same time, RTD maintains such a nature that makes it unique.

Finally, one may also observe that RTD does not imply a right to be developed or the right to live in a developed country. Rather, it seeks to provide an environment that is conducive to development. It is for this reason that Article 1 of the UNDRD reads '...development, in which all human rights and fundamental freedoms can be fully realized. ${ }^{25}$ It is submitted that the operative expression there is 'can be fully realized.' In effect, the purpose of RTD is to provide individuals and peoples with the opportunity to develop by creating a favourable atmosphere for development by removing any obstacle that might hinder the process of development.

\section{The Right Holder}

Traditional human rights-civil, political, economic, social and cultural rights - are generally rights which are enforceable by individuals against the state. These rights are generally known as individual rights. There are also group rights which are enforceable by groups of people as a collective. Such groups may be minority groups, indigenous communities or states claiming the right against a state or the international community as appropriate. In the case of RTD, it has

\footnotetext{
22 Article 1, UNGA, Declaration on the right to development.

23 Article 6(2), UNGA, Declaration on the right to development.

24 Aryeetey et al. 'The Right to Development Report, Ghana Country Study', unpublished report, Ghana Legal Resources Centre, December 2004.

25 Article 1, UNGA, Declaration on the right to development.
} 
two dimensions; it may be either an individual right or a collective right. The Declaration therefore names the human person as the central subject of RTD. ${ }^{26} \mathrm{It}$ also requires all states to create a favourable international atmosphere for the realisation of RTD.

The individual right to development is two-fold. Firstly, it entitles the individual to all necessary fundamental human rights and systems that will equip him to participate in the developmental process. Secondly, it entitles the individual to actually participate in and contribute to the developmental process. Under this second theme, it should be noted that the participation and contribution of individuals should be meaningful contribution. ${ }^{27}$ It should not be the sort that is solely limited to local communities providing labour (carrying bricks) to reduce government expenditure. ${ }^{28} \mathrm{~A}$ case in point is the contribution of free communal labour made by the local communities in the Sissala and Bolgatanga districts under Ghana's decentralisation program. ${ }^{29}$

As a collective right, states or smaller minority groups may claim under RTD. ${ }^{30}$ For instance Articles 22 and 23 of the African Charter implicitly empower minority groups or indigenous communities such as the Endorois of Kenya to claim the right to development against a state. ${ }^{31}$ RTD may also be exercised by a state against the international community. Generally, states are the subjects of international law and are therefore responsible for representing the interests of their citizens before the international community. In the same vein, Article 22(2) of the African Charter implicitly empowers a state to demand the creation of a favourable international atmosphere for the realisation of the right to development. ${ }^{32}$ Article 22(2) of the African Charter on Human and Peoples' Rights even makes it a duty for African states to ensure the exercise of the right to development on behalf of its peoples.

Article 2, UNGA, Declaration on the right to development.

Article 8(2), UNGA, Declaration on the right to development.

Aryeetey et al. 'The Right to Development Report, Ghana Country Study', unpublished report, Ghana Legal Resources Centre, December 2004.

29 Aryeetey et al. 'The Right to Development Report, Ghana Country Study', unpublished report, Ghana Legal Resources Centre, December 2004.

30 Article 22, African Charter on Human and Peoples' Rights, 27 June 1981, 21 ILM 58.

31 Centre for minority rights development v Kenya (2009) AHRLR 75

32 Democratic Republic of the Congo v Burundi, Uganda and Rwanda (2004) AHRLR 19. 


\section{i. $\quad$ The State as a Duty Bearer}

RTD imposes all the three kinds of duties associated with traditional human rights in different aspects. It imposes the duty to respect, the duty to protect and the duty to fulfil. ${ }^{33}$

The duty to respect the right to development is implicit in the Declaration on RTD. The Declaration requires states to create an atmosphere favourable to the realisation of RTD. ${ }^{34}$ This therefore implies a duty to refrain from those acts that will be inimical to the creation of such an atmosphere. For instance states are compelled to refrain from acts that will amount to a violation of human rights.

The duty to protect under the RTD is captured by Article 5 of the Declaration on RTD which stipulates that States shall take resolute steps to eliminate the massive and flagrant violations of the human rights of peoples and human beings affected by situations such as those resulting from apartheid, and threats against national sovereignty. In effect, RTD charges states to protect their citizens from all possible obstacles that militate against the realisation of the right to development. ${ }^{35}$

The duty to fulfil the RTD is expressed by the stipulation that states have the primary duty to create conditions favourable to the development of both individuals and peoples. ${ }^{36} \mathrm{This}$ duty of states includes the duty to formulate appropriate national development policies aimed at the constant improvement of the well-being of the entire population and of all individuals, on the basis of their active, free and meaningful participation in development and in the fair distribution of the benefits resulting there from. ${ }^{37}$

\section{ii. The International Community as a Duty Bearer}

RTD imposes a duty on all states as a community to cooperate in creating an atmosphere favourable to the realisation of the right to development. ${ }^{38}$ This is clearly a duty to be executed by the international community and not by a single state nor by a selected group of states. The state bears the primary responsibil-

\footnotetext{
Social and Economic Rights Action Centre (SERAC) and another v Nigeria, (2001) AHRLR 60.

Preamble, para. 3, UNGA, Declaration on the right to development.

Article 5, UNGA, Declaration on the right to development.

Article 8(1), UNGA, Declaration on the right to development.

Article 2(3), UNGA, Declaration on the right to development.

Preamble, UNGA, Declaration on the right to development.
} 
ity of ensuring RTD for its citizens but where the duties are beyond the ability of the state, the role of the international community comes in to play. ${ }^{39}$ The problem with this is that the international community lacks those administrative organs that can be tasked with the execution of such roles. The Declaration on RTD stipulates that this duty requires all states to engage in international cooperation with the aim of creating an atmosphere favourable to the realisation of the right to development. ${ }^{40}$

The duty to respect the right to development therefore shall require all states to abstain from undertaking any policies or activities that would impede the right to development of any state, especially developing states. ${ }^{41}$ Under the duty to protect, the international community may have to put in place measures that protect citizens from both domestic and foreign state that threaten their enjoyment of the Right to Development. It has actually been suggested that the international community may even have to interfere with state sovereignty in order to protect citizens from their corrupt states. Lastly the duty to fulfil requires the formulation of international developmental policies that will aid in the realisation of the right to development. ${ }^{42}$ One may observe that this brief examination of the duty of the international community under the Right to Development raises some political concerns. It may thus be observed that one of the main obstacles to consensus on the right to development is more a political one than a legal formulation one.

The requirement of international cooperation under RTD has been argued by some factions as a requirement for fair international trade regimes and the removal of burdening debt deficits ${ }^{43}$. It has also been argued as a demand for an equal share in the wealth of the world economy. 'Does this mean that the right to development should be construed as a right to 'development assistance' or 'a right to everything?'45 It is submitted that the answer to this question is No. RTD requires that states create a favourable atmosphere for the realisation of the right through international cooperation. It does not oblige developed countries to donate to less developed countries. Rather, RTD requires that an international legal framework that supports the realisation of the right is created. Therefore, such 'favourable'

\footnotetext{
Felix Kirchmeier, 'The right to development- where do we stand?' 9.

Article 3(2), UNGA, Declaration on the right to development

Article 3(3), UNGA, Declaration on the right to development

Article 4(1), UNGA, Declaration on the right to development

Felix Kirchmeier, 'The right to development- where do we stand?' 9.

Bedjaoui M, The right to development, 1177.

Felix Kirchmeier, 'The right to development- where do we stand?’ 9.
} 
environment may be rather construed within the terms of multilateral agreements that seek to level the playing field by introducing fair market policies and abstention from international practices that would hinder the realisation of the right to development. Development assistance should remain the prerogative of donor states through their foreign aid policies subject to the dictates of the right to development. It is therefore proposed that the discourse on RTD should be rather focused on the actual legal implementation of RTD. The focus should be geared towards providing viable solutions to remove the obstacles that impede the realisation of the Right to Development.

\section{Justiciability and Legal Enforcement of RTD at the Global Stage}

There is no treaty that directly makes the obligations under RTD legally binding on states. It therefore stands to reason that a right which is not opposable by the right holder against the duty bearer is not a right in the full legal sense. ${ }^{46}$ For this reason, lawyers of the positivist school of thought believe that if a right is not legally enforceable, it cannot be regarded as a human right and should only be accorded the status of a social aspiration. ${ }^{47}$ Be that as it may, RTD has been recognized as a legitimate fundamental human right. ${ }^{48}$ Consequently, the non-enforceability of RTD as against its recognition as a fundamental human right challenges world leaders to secure the justiciability of RTD globally through international law. ${ }^{49}$ Thus, it is very important to critically analyze the legal implications of RTD because the conflicting views on its justiciability impede its realization. ${ }^{50}$

In light of this conundrum, it has been suggested that RTD may still be enforced vicariously through other legally binding conventions. ${ }^{51}$ The basis of this proposition is that the content of RTD is such that its legal foundation includes civil, political, social, economic and cultural rights which may be realized through

\footnotetext{
46 Bedjaoui M, The right to development, 1177.

47 Olajumoke O. Oduwole, "International law and the right to development: A pragmatic approach for Africa”, Prince Claus Chair in development and equity 2013/2015, The Hague, 20 May 2014

48 Vienna declaration and programme of action: Note by the secretariat, world conference on human rights, Part I, [10, U.N. Doc. A/CONF. 157/23 (1993)

49 Bedjaoui M, The right to development, 1177.

50 Olajumoke O. Oduwole, "International law and the right to development: A pragmatic approach for Africa”, Prince Claus Chair in development and equity 2013/2015, The Hague, 20 May 2014

51 Felix Kirchmeier, 'The right to development- where do we stand?' 9.
} 
the enforcement of the International Bill of Rights. ${ }^{52}$ The legal foundation of RTD therefore has to be sought in the Universal Declaration on Human Rights (UDHR) which has attained the status of customary international law, the International Convention on Civil and Political Rights (ICCPR) and the International Convention on Economic, Social and Cultural Rights (ICESCR). In effect, this approach seeks to guarantee the realization of RTD by identifying with other binding international treaties that also ensure the basic tenets of RTD.

\section{i. The African Peoples' Right to Development}

The African Charter is the only multilateral treaty that makes the right to development binding by making provision for a people's right to development (PRTD). This treaty however does not have universal application. It is only binding on the member states of the African Union such as Ghana.

Article 22 (1) of the African Charter provides that all peoples on the African continent have a right to their economic, social and cultural development with due regard to their freedom and identity and in the equal enjoyment of the common heritage of mankind. ${ }^{53}$ The Charter therefore provides that the right to development is a collective right exercisable by a 'people.' This right entitles such peoples to a right to development as it pertains to their freedom and identity as a people and also as regards their interest in the wealth of the world termed as 'the common heritage of mankind.' The African Charter, however, does not provide any further details on the content of the right.

Article 22(2) further complements the right with a duty for all member states either individually or collectively to ensure the exercise of the right to development. A simple analysis of this duty will reveal that Article 22 requires states to put in place national measures to ensure the realization of the right. Also, African states are obliged to enter into regional multilateral agreements that will ensure the enjoyment of the right. Once more, the African Charter does not provide further insight into what these duties involve.

It has been suggested that the legal enforcement of RTD should adopt a pragmatic approach. ${ }^{54}$ This pragmatic approach demands that the focus should be aimed at the negative legal obligation of states to refrain from undertakings

Felix Kirchmeier, 'The right to development- where do we stand?' 9.

Article 22, African Charter on Human and Peoples' Rights.

54 Olajumoke O. Oduwole, "International law and the right to development: A pragmatic approach for Africa," Prince Claus Chair in development and equity 2013/2015, The Hague, 20 May 2014. 
that inhibit the realization of RTD. The purpose of this approach is to make the legal obligation of duty-bearers more tangible and easier to enforce. Be that as it may, the African Commission has had opportunity to shed more light on the legal enforcement of RTD.

In Sudan Human Rights Organization \& Another v Sudan, ${ }^{55}$ the African Commission defined the concept of peoples' rights thereby establishing who qualifies to claim under PRTD. The Commission held that the concept of a 'people' includes certain characteristics that either the group may use to identify themselves or which other people may use to identify them. These characteristics may include the language, religion and culture, the territory they occupy in a state, common history, and ethno-anthropological factors. ${ }^{56}$ Therefore by these standards, the 'Darfurian' people qualified to claim under Article 22 against the government of Sudan.

In the landmark case of Centre for Minority Rights Development $v$ Kenya,${ }^{57}$ the African Commission laid down the principle that established the duties of states in relation to PRTD. It was held that RTD was a two-pronged test which was both constitutive and instrumental. The commission further held that recognizing RTD requires the fulfilment of the following criteria: 'it must be equitable, non-discriminatory, accountable, participatory and transparent with equity and choice as the over-arching principles of the right to development. ${ }^{58}$ The Commission consequently applied this principle and found that the respondent state violated Article 22 by failing to respect the freedom of choice of the indigenous group because it did not conduct adequate consultations with the indigenous communities before displacing them.

Furthermore, in Democratic Republic of the Congo (DR Congo) v Burundi, Uganda and Rwanda, ${ }^{59}$ where DR Congo sued its neighbors, it was held that the deprivation of a people's right to freely dispose of their wealth and natural resources occasioned a violation of Article 22 of the African Charter. In the same case, it was also held that the indiscriminate killings and mass burial of victims' bodies was an affront to the cultural development of the Congolese people under Article 22 of the African Charter. This case perfectly illustrates how a state operates as a right holder of RTD and the negative obligation on

\footnotetext{
55 Sudan human rights organization \& another v Sudan (2009) AHRLR 153.

56 Sudan human rights organization \& another v Sudan (2009) AHRLR 153.

57 Centre for minority rights development v Kenya (2009) AHRLR 75.

58 Centre for minority rights development v Kenya (2009) AHRLR 75.

59 Democratic Republic of the Congo v Burundi, Uganda and Rwanda (2004) AHRLR 19.
} 
states to refrain from any undertaking that could hinder the right to development in any way.

It, however, appears that there may be some limitations to PRTD. In Association pour la Sauvegarde de la Paix au Burundi v Kenya, Uganda, Rwanda, Tanzania, Zaire (DRC), Zambia, ${ }^{60}$ and the African Commission held that the right to development may be subject to overriding interests such as international peace and security. The Commission explained that there was no violation of Article 22 where the respondent states had imposed an embargo on Burundi in an attempt to discourage the civil strife in the country. This is because they also had a legitimate interest in the peace and security of that region.

Moreover, the duty of states to ensure the fulfilment of RTD is subject to the doctrine of progressive realization. In Gunme and Others v Cameroon, ${ }^{61}$ the African Commission had the opportunity to establish the role of states in the provision of basic amenities under the Right to Development. It was held that the obligation of States is to invest its resources in the best possible way to attain progressive realization of the right to development. The Commission explained that although this process may not satisfy all parties in the state, it is not enough to occasion a violation of Article 22.

One cannot help but admit that the decisions of the African Commission examined under this section lay the foundation for the legal enforcement and justiciability of RTD. Admittedly, the case law on the right to development is not voluminous but the work of the Commission so far is invaluable to the legal analysis of the right to development.

\section{ii. The Justiciability and the Enforcement of the Right to Development Under the Constitution of Ghana}

The 1992 Constitution of Ghana (hereinafter called 'the Constitution') contains a comprehensive bill of rights in its Chapter Five. The bill of rights under the Constitution provides for civil and political rights such as the protection of individual liberty as well as socio-economic rights like the right to education. ${ }^{62}$ However, there is no express mention of the right to development under the Constitution of Ghana. It is nonetheless important to note that the Constitution

\footnotetext{
${ }_{60}$ Association pour la sauvegarde de la paix au Burundi v Kenya, Uganda, Rwanda, Tanzania, Zaire (DRC), Zambia (2003) AHRLR 111.

61 Gunme and others v Cameroon(2009) AHRLR 9.

62 See Articles 14 and 25, Constitution of Ghana (1992).
} 
of Ghana is dualist and therefore any signed international treaty may be legally enforceable in Ghana if it is ratified by an Act of Parliament.

So far, this study has revealed that the provisions of RTD embodied in the UN Declaration for the Right to Development are soft law. Also, it has shown that the African Charter on Human and People's Rights makes the right to development legally binding through PRTD. Therefore, it would appear that PRTD should at least be legally enforceable in Ghana. Yet, there is no legislation or judicial precedent pronouncing PRTD as justiciable or legally enforceable in Ghana. Therefore, the following sections shall attempt to determine if the right to development is justiciable or legally enforceable in Ghana by examining the enforcement of international law and general human rights under the Constitution.

\section{iii. Enforcement of International Law under the Constitution}

The hierarchy of laws recognized by the 1992 Constitution does not include international law. ${ }^{63}$ It does, however, recognize enactments made by or under the authority of the Parliament established under the Constitution. ${ }^{64}$ Furthermore, Article 75(2) of the Constitution stipulates that any international treaty or convention executed by the President shall be subject to ratification by an Act of Parliament or by a parliamentary resolution supported by the votes of more than half the members of Parliament. The combined effect of these constitutional provisions is that international treaties or conventions signed by the President of Ghana lack direct application in the courts of Ghana unless Parliament approves such a treaty either through the mechanism of an Act of Parliament or a parliamentary resolution.

It has been suggested that there are four ways in which an international treaty may be incorporated into municipal law. ${ }^{65}$ The first means is by direct incorporation of the particular international treaty into the Constitution of the legal system, an Act of Parliament or a bill of rights. ${ }^{66}$ The second means is through transformation or incorporation where a statement in the preamble of a legislation expressly states that the legislation in question is giving legal effect to an international treaty or convention. ${ }^{67}$ Thirdly, an international instrument may

63 Article 11, Constitution of Ghana (1992).

${ }^{64}$ Article 11 (1) (b), Constitution of Ghana (1992).

65 Appiagyei Atua K, 'Ghana at 50: The place of international human rights norms in the courts' in Bonsu H et al (eds) Ghana since independence: History, development and prospects, 2007, 118.

${ }_{66}$ Appiagyei Atua K, 'Ghana at 50: The place of international human rights norms in the courts', 118.

67 Appiagyei Atua K, 'Ghana at 50: The place of international human rights norms in the courts', 118 . 
be incorporated by 'inferred implementation' whereby an enacted legislation is made to give effect to the obligations spelt out in the international treaty ${ }^{68}$ Lastly, incorporation may be done through legislation that indirectly gives effect to treaty commitments without directly making reference to the particular international instrument. $^{69}$

Interestingly, Ghana has signed a large number of international treaties and conventions including the African Charter on Human and People's Rights. ${ }^{70}$ However, it is quite unfortunate that the Parliament of Ghana has not ratified nearly as many treaties and conventions including the African Charter on Human and Peoples Rights. ${ }^{71}$ It would therefore appear that the provisions of the African Charter are not applicable in the Ghanaian courts. Be that as it may, Article 40 of the Constitution imposes a duty on the government of Ghana to promote respect for treaty obligations and adhere to principles enshrined in international organizations of which Ghana is a member. ${ }^{72}$ Article 40 of the Constitution therefore empowers the courts in Ghana to hold the government of Ghana accountable to all its obligations under the international treaties and conventions it has signed but is yet to ratify. This includes the obligations of Ghana under the African Charter such as the exercise of the right to development under Article 22 of the African Charter. It is therefore submitted that the rights and obligations enshrined under PRTD can be enforced in the Ghanaian courts against the government of Ghana.

This assertion is supported by the decision in the case of New Patriotic Party v Inspector General of Police. ${ }^{73}$ In this case, the Supreme Court relied on international law and stated per Archer CJ that the African Charter can be relied upon although a specific legislation had not been passed to give effect to it. He reasoned that this was because Ghana was a signatory to the African Charter and therefore had a duty to recognize the rights, duties and freedoms enshrined in the Charter. ${ }^{74}$

\footnotetext{
68 Appiagyei Atua K, 'Ghana at 50: The place of international human rights norms in the courts', 118.

69 Appiagyei Atua K, 'Ghana at 50: The place of international human rights norms in the courts', 118.

70 Quansah E K, 'An examination of the use of international law as an interpretative tool in human rights litigation in Ghana and Botswana' in Killander M (ed), International law and domestic human rights litigation in Africa, Pretoria University Law Press, 2010, 37.

71 Quansah E K, 'An examination of the use of international law as an interpretative tool in human rights litigation in Ghana and Botswana', 37.

72 Article 40 (c) and (d), Constitution of Ghana (1992).

73 New Patriotic Party v Inspector General of Police [1993-94] 2 GLR 459.

74 New Patriotic Party v Inspector General of Police [1993-94] 2 GLR 459.
} 
It is therefore submitted that the provisions of the African Charter on the right to development are capable of application by the Ghanaian courts. This is because Article 40 of the Constitution empowers the Ghanaian courts to hold the government of Ghana accountable to its obligations under international instruments, such as the African Charter, that have been signed but are yet to be ratified. It should, however, be noted that Article 40 of the Constitution is captured under the Directive Principles of State Policy in chapter 6. The justiciability of these directive principles are limited to some extent and shall be discussed in a later section.

\section{iv. General Enforcement of Human Rights Under the Constitution}

The Constitution of Ghana makes provision for a bill of rights in Chapter 5. The bill of rights provides for civil and political rights as well as socio-economic rights which are all enforceable. In that vein, Article 33 of the Constitution provides a mechanism for the enforcement of fundamental human rights under the Constitution. Article 33(1) stipulates that any person alleging a violation of their fundamental human rights may apply to the High Court which is empowered to make the appropriate orders to give effect to the provisions of Chapter $5 .^{75}$ The personal interest requirement under Article 33 therefore does not make room for public interest litigation.

However, the Supreme Court of Ghana has held that a person without a personal interest in a human rights claim may sue under Article 2 of the Constitution if the suit is in the public interest. ${ }^{76}$ It is also interesting to note that the wording of Article 33(1) suggests that there are avenues other than the High Court where an aggrieved person can seek redress for a violation of their human rights. The Commission on Human Rights and Administrative Justice, whose functions include investigation of complaints of human rights violations is one such 'lawful avenue' within the contemplation of Article 33(1). ${ }^{77}$ In effect, one may observe that the Constitution has an elaborate mechanism put in place for the enforcement of fundamental human rights recognized under the Constitution.

In relation to the right to development, Chapter 5 does not make any express provision for it. It is, however, submitted that the bill of rights under the

\footnotetext{
75 Article 33(2), Constitution of Ghana (1992).

76 Adjei - Ampofo v Accra metropolitan assembly and attorney general (No 1) [2007-2008] SCGLR 611; see also Sam (No2) v attorney general [2000] SCGLR 305

77 See Articles 216 and 218, Constitution of Ghana (1992).
} 
Constitution implicitly enforces the right to development. This study has revealed that both civil and political rights as well as socio-economic rights form the basic foundations of the right to development. Therefore, the joint operation of both civil and political rights, together with socio-economic rights under the Constitution guarantees the enjoyment of the right to development in Ghana. The right to development is therefore indirectly enforceable through the direct enforcement of civil, political, social and economic rights already provided for by the Constitution.

Moreover, the right to development is enforceable under the provisions of Article 33(5) of the Constitution. The Constitution does not make express provision for a right to development. However, Article 33(5) of the Constitution provides that human rights which have not been specifically mentioned in chapter 5 of the Constitution are applicable so far as they are rights which are inherent in a democracy and intended to secure the freedom and dignity of mankind. There is no judicial pronouncement on the meaning and scope of rights "considered to be inherent in a democracy and intended to secure the freedom and dignity of mankind." However, in the case of Ghana Lotto Operators Association v National Lottery Authority, the Supreme Court of Ghana stated that in order to enforce the provision of Article 33(5), a person must allege violation of fundamental human rights which have not been specifically mentioned by chapter 5 of the Constitution but which have been provided for by international instruments such as the African Charter. ${ }^{79}$ It is therefore submitted that those fundamental human rights which are not specifically mentioned in chapter 5 of the Constitution but are guaranteed in international treaties are rights to be considered as inherent in a democracy and intended to secure the freedom and dignity of mankind. In that vein, it is further submitted that the right to development captured under Article 22 of the African Charter is enforceable under Article 33(5) of the Constitution as a right inherent in a democracy and intended to secure the freedom and dignity of mankind.

\section{Fundamental Human Rights and the Directive Principles of State Policy}

Admittedly, the Constitution does not make express mention of the right to development. However, there are certain provisions that give effect to the

\footnotetext{
Article 33(5), Constitution of Ghana (1992).

Ghana Lotto Operators Association and others v National Lottery Authority [2007-2008] 2 SCGLR 1088.
} 
commitments recognized under RTD. For instance, Article 40(b) stipulates that the government shall seek the establishment of a just and equitable international economic and social order. One may observe that Article 40(b) of the is very similar to paragraph 3 of the preamble to the Declaration to RTD and to Article 3(3) of the same declaration which also recognizes the need for an international economic and social order in order to secure the realization of RTD. Moreover, Article 37 also contains provisions that indirectly give effect to state obligations recognized under RTD. For instance, Article 37 (2) (a) makes provision for the participation of the individual in the developmental process. In the same vein, Article 37 (3) stipulates that the government of Ghana 'shall be guided by international buman rights instruments which recognize and apply particular categories of human rights to the development process.' It would therefore appear that certain elements of the right to development find expression in the Constitution. The main question, however, is if these provisions captured under the Directive Principles of State Policy can be interpreted as fundamental human rights justiciable under the Constitution.

It has also been argued in preceding paragraphs that Article 40 of the Constitution imposes a duty on the government of Ghana to adhere to its obligations under treaties such as the African Charter. Consequently, it was then submitted that the Ghanaian courts could hold the government of Ghana accountable to its treaty obligations under the African Charter. In view of this, it is important to point out Article 40 of the falls under the Directive Principles of State Policy. Thus, the issue of whether or not the Ghanaian courts can hold the government of Ghana accountable to its obligations under the African charter is dependent on justiciability or otherwise of chapter 6 .

As stated earlier, Article 33(5) of the Constitution recognizes other fundamental human rights that are not expressly mentioned under Chapter 5 of the Constitution. This sub-section shall make an attempt to determine if other provisions of the not captured under Chapter 5 of the Constitution but rather captured under Chapter 6 may be interpreted as fundamental human rights equally enforceable under the Constitution.

Chapter 6 of the 1992 Constitution provides for the Directive Principles of State Policy ${ }^{80}$ Article 34(1) of the Constitution provides that the Directive Principles of State Policy shall guide all citizens and state institutions as well as political parties in the application and interpretation of the Constitution. Chapter

80 See Articles 34 to 41, Constitution of Ghana (1992). 
6 therefore operates as a guide to the interpretation of the Ghanaian Constitution and the laws of Ghana. It also serves as a policy guide for government and a yardstick against which the Ghanaian people can measure the performance of their government. On the question of the justiciability of the directive principles, it has been suggested by the Committee of Experts of the Draft Constitution 1992 that the directive principles are not in themselves justiciable and enforceable but are nothing more than mere guides to interpretation and construction. ${ }^{81}$

Fortunately, the Supreme Court of Ghana has made some judicial pronouncements on the justiciability of the Directive Principles of State Policy captured under Chapter 6.The first case to make a judicial pronouncement on the justiciability of chapter 6 is New Patriotic Party v Attorney-General (31 ${ }^{\text {st }}$ December Case).$^{82}$ In this case, it was held that the Directive Principles of State Policy are justiciable. The basis of that decision was that the Constitution as a whole is a justiciable document and that if any part of the Constitution was non-justiciable, the Constitution itself had to state it. The court therefore reasoned that in the absence of such internal evidence, the Directive Principles of State Policy are justiciable and can be applied by the courts. This decision therefore establishes that the justiciability of the provisions in chapter 6 is unqualified.

The Supreme Court of Ghana reached a different conclusion in the case of New Patriotic Party v Attorney-General (Ciba Case). ${ }^{83}$ Here, the plaintiff contended that the Council of Indigenous Business Associations Law 1993 (PNDCL 213) is inconsistent with and in contravention ofArticles 21(1) (e) and 37 (2) (a) and (3). The Attorney-General raised a preliminary objection on the grounds that the claim of the plaintiff was based on Directive Principles of State Policy captured under Chapter 6 of the Constitution and was therefore not justiciable. The Supreme Court unanimously dismissed the preliminary objection and held that although the Directive Principles of State Policy were not justiciable in themselves they served as goals for legislative programs and guides for judicial interpretation.

However, the Court (per Bamford Addo and Sophia Akuffo JJSC) explained that the Directive Principles of State Policy were not completely non-justiciable. In some cases, the provisions of chapter 6 of the may be held to be justiciable. These are cases where the provisions in chapter 6 do not stand on their own but

\footnotetext{
81 Bimpong-Buta S Y, The Role of the Supreme Court in the development of Constitutional Law in Ghana, Advanced Legal Publications, 2007, 348.

82 New Patriotic Party v Attorney-General [1993-94] 2 GLR 35.

83 New Patriotic Party v Attorney General (Ciba Case) [1996-97] SCGLR 729.
} 
qualify rights already provided for in chapter 5 . The Court reasoned that those provisions in Chapter 6 that qualified other human rights provisions and specific guarantees such as the right of association could be interpreted as justiciable only on those terms. Therefore, the decision of the Court is that directive principles of state policy are justiciable in so far as they qualify other human rights provisions. The example given by Sophia Akuffo JSC in that case was that Article 37(2) (a) and (3) qualified Article 21(1) (e) and is therefore justiciable on those terms. It is thus submitted that this decision generally raises a presumption of non-justiciability against the provisions in chapter 6 . This presumption is only rebutted on a case by case analysis where the circumstances of the case indicate that the provisions in chapter 6 qualify a substantive right provided for in chapter 5 .

Interestingly, in the more recent case of Ghana Lotto Operators v National Lottery Authority, the Supreme Court of Ghana adopted a different approach to the justiciability of the Directive Principles of State Policy ${ }^{84}$ It was held that these directive principles are presumed to be justiciable unless the provisions lend themselves to an interpretation which renders them unenforceable. The court explained that although the directive principles are presumed to be justiciable, under certain circumstances, certain provisions in chapter 6 would not be enforceable. The distinction between the decision in Ghana Lotto Operators v National Lottery Authority and the decision in New Patriotic Party v AttorneyGeneral (Ciba Case) is that the former decision unlike the latter raises a presumption of justiciability in favor of the provisions in chapter 6. The Supreme Court in the Ghana Lotto Operators case held that all the prior decisions on the justiciability of chapter 6 including the decision in the Ciba case did not lay down binding precedent. This is because both prior decisions on the justiciability of the provisions in chapter 6 are conflicting. The court therefore took that opportunity to lay down a new principle.

The issue to be addressed now is if the provisions in Articles 40, 37 (2) (a) and (3) which implicitly give effect to the right to development are justiciable. It appears that there is no binding decision in Ghana on the justiciability or otherwise of the Directive Principles of State Policy. This is because the Supreme Court decisions discussed above establish different principles. The $31^{\text {st }}$ December case held that the provisions in chapter 6 are justiciable without qualification. The Ciba case held that the directive principles were by themselves non-justicia-

84 Ghana Lotto Operators Association and others v National Lottery Authority [2007-2008] 2 SCGLR 1088. 
ble except where they qualified substantive rights in Chapter 5. The Ghana Lotto Operators case on its part held that the provisions in chapter 6 were generally justiciable except in cases where the provisions lend themselves to an interpretation that renders them unenforceable. In view of this, this study will apply the decision in the Ghana Lotto Operators case. It is thus submitted that the provisions in Articles 40, 37 (2) (a) and (3) which implicitly give effect to the right to development are justiciable. This means that those provisions which enforce commitments recognized under RTD are enforceable in the Ghanaian courts. It also follows that the earlier argument raised that the Ghanaian court can hold the government of Ghana accountable to its treaty obligations is valid. This is because the justiciability of the Directive Principles of State Policy includes Article 40 which empowers the courts to hold the government so accountable is also justiciable.

It is admitted that the implicit reference to the right to development in the Constitution may not be as extensive as is desirable. However, this does not erode the existence of the right to development under the Ghanaian Constitution. This is because Article 33(5) of the Constitution empowers the courts to apply Article 22 of the African Charter. Furthermore, the courts may make reference to the decisions of the African Commission on the enforcement of the right to development. That is to say, there is a source of persuasive case law the courts may resort to for assistance in interpretation and enforcement of the right to development.

\section{Conclusion and Recommendation}

The aim of this study is to determine if the right to development is justiciable and legally enforceable by the Ghanaian courts. In order to do so, the study has examined the contents of RTD under the UNDRD, analyzed RTD under Article 22 of the African Charter and examined its application under the Constitution of Ghana.

\section{i. Conclusions}

The conclusions reached by this study shall be summarized in the following points:

1. The Ghanaian courts may enforce the right to development either as international law or as a human right implicitly guaranteed under the 
Constitution of Ghana. This is in spite of the fact that the African Charter has not been formally incorporated into national law and neither is RTD specifically mentioned in the Constitution. This claim is supported by the following arguments:

a) Although the African Charter has not been formally incorporated into national law, Article 40 empowers the Ghanaian court to hold the government of Ghana accountable to its treaty obligations under the African Charter. Also, Article 33(5) of the Constitution opens the door for the courts to enforce Article 22 of the African Charter as a fundamental human right under the Constitution.

b) Although the Constitution does not make specific mention of the right to development, it is implicitly guaranteed through the joint operation of civil and political rights as well as socio-economic rights. Thus, the right to development to a certain extent may be enforceable under Article 33 of the Constitution.

c) The provisions of Chapter 6 that guarantee the right to development under the Constitution are justiciable. The courts may therefore apply them in the enforcement of the right to development under the Constitution.

2. Although, the UN DRD is soft law, the right to development captured under Article 22 of the African Charter imposes binding obligations on member states of the African Union including Ghana. Ghana may thus be held accountable under the African Charter. Furthermore, the judicial decisions of the African Commission on the enforcement of the right to development serve as persuasive precedent for national courts.

\section{ii. Recommendations}

1. It has been observed that there is no case law on the right to development in Ghana. It is suggested that this is a result of the fact that lawyers do not base their arguments on violations of the right to development. In effect, the Ghanaian Courts have not been granted the opportunity to pronounce on the justiciability or otherwise of the right to development under the Constitution of Ghana. It is therefore 
recommended that legal practitioners submit arguments on the right to development when presenting their cases before the courts. This will grant the courts the opportunity to decide on the justiciability of the right to development.

2. It is also recommended that the Courts encourage public interest litigation by adopting a liberal approach to questions of capacity and standing. This would make it easier for interested parties to institute actions before the Courts in order to promote the enforcement of the right to development under the Constitution. It would also encourage civic responsibility on the part of citizens who are more financially capable of instituting suits before the courts. This would go a long way to promote the enforcement of the right to development in Ghana.

3. Lastly, it is recommended the courts adopt a liberal approach to the interpretation and enforcement of the right to development. It is submitted that adopting a liberal approach to construe the right to development in line with the spirit of the Constitution would promote the enjoyment of the right under the Constitution. 